\title{
Keragaan Agronomik Populasi F4 Hasil Persilangan Padi IR 36 dengan Padi Merah PWR
}

\author{
Agronomic Performance of F4 Population Derived from the Cross of IR 36
}

\author{
and Red Rice PWR
}

\author{
Suprayogi, Mei Ary Praptiwi", Ahmad lqbal, Tri Joko Agustono \\ Pasca Sarjana Fakultas Pertanian Universitas Jenderal Soedirman Purwokerto \\ Jl. Dr. Soeparno No.63, Karang Bawang, Grendeng, Kec. Purwokerto Utara, Kabupaten \\ Banyumas, Jawa Tengah 53122 \\ *) Penulis untuk korespodensi E-mail: meiarypraptiwi@yahoo.co.id \\ Diajukan: 7 Juni 2018 /Diterima: 23 Maret 2021 /Dipublikasi: 25 Mei 2021
}

\begin{abstract}
Effort to increase production and nutritional quality of Red Rice is done by crossing IR 36 and Red Rice PWR varieties to obtain Red Rice breeding lines with good palatability. The objectives of the study were to know the agronomic performance of the F4 population derived from the cross of IR36 and Red Rice PWR; to get F4 breeding lines that can be continued to be F5 generation; and to determine amylose content of the selected breeding lines. The research was conducted in the rice field of Mersi Village, East Purwokerto District, Banyumas Regency. Augmented Complete Randomized Block Design with three replicates was used to arrange the F4 breeding lines and the check varieties of Black Rice, Mentik Wangi, IR 36 and Red Rice PWR. The results showed transgresive segregations were still observed on flowering date, number of grain per tiller, panicle length and grain weight per hill. However, no difference were detected on plant height, number of productive tillers, total tillers and weight of 1000 seeds. Based on the segregating agronomic characters and the amylose content, four breeding lines, that are, IRPM 114218284, IRPM 114218224, IRPM 11224542, IRPM 11224543 were selected to be continued as F5 generation. The selected breeding lines have medium amylose content.
\end{abstract}

Keywords: agronomic performance; IR 36; population F4; Red Rice PWR

\section{INTISARI}

Upaya peningkatan produksi dan memperbaiki tekstur beras merah dilakukan dengan menyilangkan padi varietas IR36 dan Padi Merah PWR untuk menghasilkan galur padi merah yang bertekstur pulen. Tujuan penelitian adalah: untuk mengetahui keragaan agronomik populasi F4 hasil persilangan IR 36 dan Padi Merah PWR; untuk mendapatkan galur-galur F4 yang akan dilanjutkan menjadi generasi F5; dan untuk mengetahui kadungan amilosa galurgalur terseleksi. Penelitian dilaksanakan di lahan sawah Desa Mersi, Kecamatan Purwokerto Timur, Kabupaten Banyumas. Rancangan Acak Kelompok Lengkap (RAKL) ter-augmentasi dengan tiga ulangan digunakan untuk menempatkan galur-galur dan varietas cek (Padi Hitam, Mentik Wangi, IR 36 dan Padi Merah PWR). Hasil penelitian menunjukkan masih adanya segregasi transgresif pada karakter umur berbunga, jumlah gabah permalai, panjang malai dan bobot gabah per rumpun, sedangkan tinggi tanaman, jumlah anakan produktif, jumlah anakan total dan bobot 1000 biji sudah seragam. Berdasarkan karakter agronomik yang masih bersegregasi dan analisis kandungan amilosa terpilih empat galur yang 
dilanjutkan menjadi generasi F5 yaitu: IRPM 114218284, IRPM 114218224, IRPM 11224542, IRPM 11224543. Individu terpilih memiliki kandungan amilosa dalam kategori sedang.

\section{Kata kunci: keragaan agronomik; IR 36; populasi F4; Padi Merah PWR.}

\section{PENDAHULUAN}

Perbaikan kualitas gizi beras melalui pembentukan varietas unggul baru merupakan salah satu tujuan pemuliaan tanaman padi. Seleksi terhadap galur-galur yang bersegregasi adalah tahapan penting dalam proses pembentukan varietas unggul. Pemilihan galur yang masih bersegreagsi efektif apabila tersedia informasi genetik antara lain, keragaman genetik, heritabilitas, dan kemajuan genetik (Carsono, 2009). Perakitan varietas padi jenis khusus menitikberatkan pada potensi hasil yang tinggi disertai peningkatan kandungan gizi dan tekstur nasi yang pulen. Peningkatan kualitas gizi beras bermanfaat bagi kesehatan sehingga dapat untuk mengatasi masalah kekurangan pangan dan gizi.

Beras merah diketahui bermanfaat bagi kesehatan karena mengandung vitamin B kompleks yang cukup tinggi, asam lemak esensial, serat maupun zat warna antosianin yang sangat bermanfaat bagi kesehatan (Suardi, 2005), sedangkan padi varietas IR 36 merupakan padi dengan kadar amilosa sebesar $25 \%$ danmemiliki indeks glikemik rendah yaitu sebesar 45. Persilangan padi IR 36 sebagai tetua betina dan Padi Merah PWR sebagai tetua jantan dilakukan karena masing-masing memiliki karakteristik yang berbeda. Tahapan pemuliaan diawali dengan pemilihan tetua, dilanjutkan dengan persilangan dan seleksi galur-galur yang sedang bersegegasi. Karagaan agronomik merupakan ciri khas tanaman yang dapat menentukan produktivitas. Seleksi tanaman berdasarkan karakter agronomik pada galur yang masih bersegegasi dilakukan untuk mendapatkan galur harapan. Galur-galur terpilih selanjutnya akan diuji pada generasi berikutnya (Perwira, 2004). Selain mendapatkan galur dengan produktivitas tinggi, evaluasi terhadap kandungan amilosa pada galur-galur terpilih dilakukan untuk mendapatkan galur dengan kandungan amilosa rendah dengan tekstur nasi pulen. Perubahan mutu beras pada galur-galur terpilih tidak hanya dipengaruhi oleh genetik tanaman, tetapi juga dipengaruhi oleh lingkungan tumbuh. Menurut Mc Clung (2000), bahwa perbedaan tekstur nasi dipengaruhi oleh lingkungan tumbuh berbeda. tekstur nasi dipengaruhi oleh komposisi kimia yaitu kandungan amilosa pada biji (Ashley, 1996).

Tujuan penelitian adalah: untuk mengetahui keragaan agronomik galur-galur F4 hasil persilangan IR 36 dan Padi Merah PWR, untuk mendapatkan galur-galur F4 dari persilangan IR 36 dan Padi Merah PWR yang akan dilanjutkan menjadi generasi F5, dan untuk mengetahui kandungan amilosa pada galur-galur terpilih.

\section{BAHAN DAN METODE}

Penelitian dilaksanakan di lahan sawah Desa Mersi, Kecamatan Purwokerto Timur, Kabupaten Banyumas dari bulan Juni sampai September 2016. Galur-galur yang diuji adalah: IRPM 1122454, IRPM 1121944, IRPM 1121956, IRPM 1122347, IRPM 1142194, IRPM 1142182, 
dan IRPM 112192. Sebagai varietas cek digunakan varietas Padi Hitam, Mentik Wangi, IR 36 dan Padi Merah. Jumlah total tanaman yang ditanam adalah 501 tanaman.

Rancangan yang digunakan dalam penelitian ini adalah rancangan acak kelompok lengkap (RAKL) ter-augmentasi (Augmented design dengan rancangan dasar RAKL). Augmented design digunakan untuk mengantisipasi bahan genetik yang tersedia sangat terbatas. Pada rancangan augmented, bahan genetik (galur) disebut perlakuan dan tidak dilakukan pengulangan dalam setiap blok, sedangkan pada varietas cek dilakukan pengulangan disebut dengan kontrol dan ditanam dengan cara disisipkan secara acak diantara galur-galur (Federer, 1961). Karakter agronomik yang diamati adalah tinggi tanaman, jumlah anakan total, jumlah anakan produktif, umur berbunga, panjang malai, jumlah gabah per malai, bobot 1000 biji, bobot gabah per rumpun, dan kandungan amilosa pada tanaman terpilih. Pengambilan data dilakukan pada setiap tanaman dalam setiap galur, karena setiap tanaman mewakili genetik yang berbeda, dan hal yangm sama juga dilakukan pada setiap tanaman varietas cek.

\section{HASIL DAN PEMBAHASAN}

\section{Evaluasi Karakter Agronomik Populasi F4}

Hasil analisis menunjukkan bahwa blok tidak berpengaruh nyata terhadap keragaan agronomik galur-galur yang diuji, kecuali pada bobot gabah per rumpun (Tabel 1) yang menunjukkan bahwa lingkungan yang diguna- kan untuk penelitian relatif homogen. Pengaruh blok yang tidak berbeda pada bobot gabah per rumpun diperhitungkan dalam bentuk penyesuaian data rerata (adjusted mean). Secara terpisah dilakukan analisis varian terhadap varietas cek, dan hasil analisis menunjukkan bahwa tetua persilangan IR 36 dan Padi Merah PWR berbeda pada karakter tinggi tanaman, jumlah gabah per malai dan panjang malai, sementara pada karakter lain kedua varietas tetua tersebut sama (Tabel 2).

\section{Evaluasi Blok dan Verietas Cek}

Evaluasi populasi F4 hasil persilangan IR 36 dan Padi Merah PWR dilakukan untuk memperoleh galur harapan yang mempunyai karakter agronomik ideal dan lebih baik dibandingkan tetuanya. Karakter umur berbunga, panjang malai, jumlah gabah per malai dan jumlah gabah per rumpun pada populasi F4 hasil persilangan IR 36 dan Padi Merah PWR masih beragam, sedangkan karakter agronomik yang lain sudah seragam (Tabel 3). Keragaman adalah sumber utama yang digunakan dalam seleksi, semakin beragam karakter agronomik dalam populasi maka proses seleksi menjadi efektif, tetapi sebaliknya apabila nilai keragaman kecil maka proses seleksi akan sulit dilakukan (Guimarães, 2009).

Keragaman fenotip tanaman menunjukkan adanya perbedaan karakteristik dan sifat genetik dari setiap varietas (tetua) (Sikuku et al., 2015). Karakter agronomik populasi F4 merupakan rerata karakter di antara tetuanya (Widyayanti, 2017). 
Tabel 1. Hasil analisis pengaruh blok terhadap semua variabel pengamatan pada keragaan varietas pembanding

\begin{tabular}{lll}
\hline No. & Variabel Pengamatan & Blok \\
\hline 1 & Umur berbunga & tn \\
2 & Tinggi tanaman & tn \\
3 & Jumlah anakan total & tn \\
4 & Jumlah anakan produktif & tn \\
5 & Jumlah ganah per malai & tn \\
6 & Bobot 1000 biji & tn \\
7 & Panjang malai & tn \\
8 & Bobot gabah per rumpun & $*$ \\
\hline
\end{tabular}

Keterangan: (tn) tidak nyata, $\left(^{*}\right)$ nyata.

Tabel 2. Hasil analisis uji lanjut varietas cek

\begin{tabular}{|c|c|c|c|c|c|c|c|c|c|c|c|c|c|c|}
\hline Varietas & UB & \multicolumn{2}{|c|}{ TT } & \multicolumn{2}{|c|}{ JAT } & \multicolumn{2}{|c|}{ JAP } & \multicolumn{2}{|c|}{ JGPM } & PM & \multicolumn{2}{|c|}{ BSB } & \multicolumn{2}{|c|}{ BGPR } \\
\hline IR 36 & $63,33 \mathrm{c}$ & 94,71 & a & 20 & $\mathrm{a}$ & 18,2 & c & 64,67 & $\mathrm{a}$ & 21,55 & a 23,69 & $\mathrm{a}$ & 24,68 & $a b$ \\
\hline Padi Merah & $62,67 \mathrm{c}$ & 142,1 & $d$ & 16,1 & $\mathrm{a}$ & 13,37 & $a b c$ & 125,5 & $c$ & 29,33 & d 23,83 & $\mathrm{a}$ & 29,85 & $b$ \\
\hline Padi Hitam & $61,08 \mathrm{~b}$ & 111,5 & $b$ & 17,49 & $\mathrm{a}$ & 11,28 & $a b$ & 69,98 & $a b$ & 23,52 & b 25,79 & $\mathrm{a}$ & 23,69 & $a b$ \\
\hline Mentik Wangi & 55,21 a & 127 & c & 19,16 & a & 8,54 & $\mathrm{a}$ & 85,19 & $a b$ & 27,1 & c 28,63 & $\mathrm{a}$ & 20,04 & a \\
\hline
\end{tabular}

a. Umur berbunga

Awal periode generatif tanaman padi ditandai dengan munculnya bunga. Semakin cepat tanaman memasuki fase generatif, menandakan umur tanaman semakin pendek. Fase pertumbuhan padi dibagi menjadi 3 yaitu fase vegetatif umur 0-60 hari setelah sebar (hss), fase generatif umur 60-90 hss dan fase pematangan umur 90-120 hss (Departemen Pertanian, 2000). Umur tanaman pada kategori genjah adalah 105-124 hss. Hasil analisis menunjukkan bahwa umur berbunga berbeda nyata antar galur (Tabel 3). Pola sebaran hasil persilangan IR 36 dengan Padi Merah PWR menunjukkan adanya segregasi transgresif, yaitu segregasi yang sebarannya membentuk dua gugus segregan dimana nilai keturunan lebih kecil dan lebih besar dari nilai tetuanya (Jambormias and Riry, 2009) (Gambar 1). 
Tabel 3. Hasil analisis statistik pada masing-masing variabel terhadap galur hasil persilangan IR 36 dengan padi merah.

\begin{tabular}{lll}
\hline No. & Variabel Pengamatan & Blok \\
\hline 1 & Umur berbunga & * \\
2 & Tinggi tanaman & tn \\
3 & Jumlah anakan total & tn \\
4 & Jumlah anakan produktif & tn \\
5 & Jumlah ganah per malai & $*$ \\
6 & Bobot 1000 biji & tn \\
7 & Panjang malai & $* *$ \\
8 & Bobot gabah per rumpun & $* *$
\end{tabular}

Keterangan: (IRPM) hasil persilangan IR 36 dengan padi merah, $\left({ }^{*}\right)$ beda nyata, (tn) tidak nyata, $\left({ }^{* *}\right)$ sangat nyata.

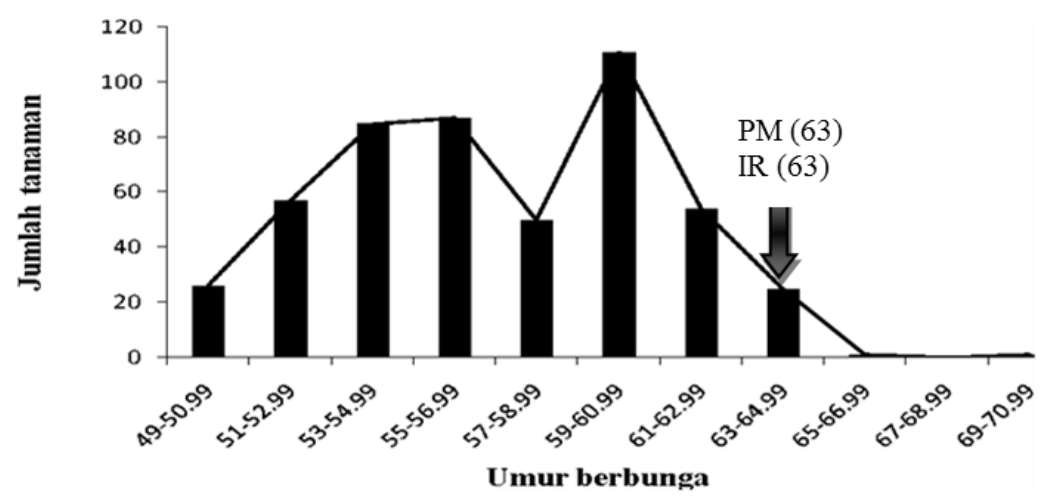

Gambar 1. Gafik pola sebaran kergaman populasi F4 hasil persilangan IR 36 dengan padi merah berdasarkan Umur Berbunga

Galur harapan dari persilangan Padi IR36 dan Padi Merah PWR adalah yang berumur genjah. Seleksi tanaman didasarkan pada kategori umur berbunga maksimal 60 hari (Departemen Pertanian, 2000). Dari 501 tanaman terdapat 355 tanaman yang memiliki umur pembungaan maksimal 60 hst. Galur terpilih memiliki umur berbunga antara 50 hari setelah tanam (hst) sampai 60 hst (Tabel 4), lebih baik dari tetuanya yaitu varietas IR 36 adalah 63 hst dan Padi Merah adalah 62 hst (Tabel 3).
Karakter umur berbunga sangat berkaitan dengan umur panen. Menurut Romadhoni et al., (2012) bahwa umur berbunga yang lebih cepat sejalan dengan umur panen, sesuai potensi genotip dan lama pengisian buah. Kelemahan dari umur pembungaan yang terlalu cepat akan berpengaruh pada jumlah anakan yang lebih sedikit (Tasliah et al., 2011). Metode seleksi dengan memilih umur berbunga yang optimal dan mempertimbangkan komponen lain yang bertujuan untuk memperbaiki genetika tanaman hasil keturunan (Yang et al., 2008). Menurut Hartina et al., (2017) salah satu penyebab 
terjadinya perbedaan umur berbunga padi adalah beragamnya periode vegetatif yang dipengaruhi oleh faktor genetik.

b. Tinggi tanaman

Tinggi tanaman tetua sangat berbeda nyata (Tabel 2). IR36 merupakan varietas padi dengan habitus rendah sedangkan Padi Merah PWR berhabitus tinggi dan berpotensi rebah. Dalam perkembangan generasi $F 4$, hasil analisis menunjukkan bahwa tinggi tanaman sudah seragam (Tabel 3). Kondisi tinggi tanaman yang sudah seragam tidak menjadi dasar utama menyeleksi individu yang akan dilanjutkan ke generasi F5.

Perbaikan karakter agronomik tinggi tanaman dilakukan dengan memilih tanaman yang memiliki nilai diantara tetuanya (Tabel 4). Seleksi galur berdasarkan kategori sedang menurut IRRI (2009) yaitu 90-125 cm. Proses seleksi pemuliaan tanaman tidak mengarah pada tanaman yang tinggi karena tanaman yang terlalu tinggi berpotensi mudah rebah dibandingkan tanaman pendek (Diptaningsari, 2013). Karakter tinggi tanaman berkaitan dengan pemanfaatan hasil fotosintesis. Tanaman padi dengan batang pendek banyak menggunakan hasil fotosistesis dibandingkan tanaman yang memiliki batang panjang (Mulyaningsih et al., 2016).

C. Jumlah anakan total

Hasil analisis pada tetua maupun populasi F4 hasil persilangan IR36 dan Padi Merah PWR untuk karakter agronomik jumlah anakan total tidak berbeda nyata (Tabel 2 dan 3). Karakter agronomik populasi F4 yang sudah seragam tidak digunakan sebagai dasar utama seleksi individu. Seleksi tanaman berdasarkan kelompok jumlah anakan kriteria banyak (>25 batang) menurut Standard Evaluaion of Rice (IRRI, 2009). Banyaknya jumlah anakan total berpengaruh terhadap banyaknya jumlah anakan produktif, semakin banyak jumlah anakan total akan diikuti oleh banyaknya jumlah anakan produktif. Semakin banyak jumlah anakan produktif akan berpengaruh terhadap meningkatnya bobot gabah per rumpun (Fadjry et al., 2012).

d. Jumlah anakan produktif

Jumlah anakan produktif berpengaruh langsung terhadap jumlah malai yang dihasilkan, semakin banyak anakan produktif maka makin tinggi jumlah gabah per rumpun (Fadjry et al., 2012). Hasil analisis varian terhadap tetua maupun populasi F4 hasil persilangan IR36 dan Padi Merah PWR menunjukan bahwa karakter jumlah anakan produktif tidak berbeda nyata (Tabel 3). Populasi F4 dikelompokkan sesuai standar jumlah anakan poduktif menurut IRRI, 2009, yaitu sangat banyak (>25 batang per tanaman), banyak (20-25 anakan per tanaman), sedang (10-19 anakan per tanaman), sedikit (59 anakan per tanaman) dan sangat sedikit $(<5$ batang per tanaman). Tanaman terpilih memiliki jumlah anakan produktif 15 batang sampai 25 batang (Tabel 4), termasuk dalam kategori sedang sampai banyak, sedangkan jumlah anakan produktif IR 36 sebanyak 18 batang dan Padi Merah hanya 13 batang. Pada populasi F4 sudah ada perbaikan karakter jumlah anakan produktif dari tetuanya.

e. Panjang malai

Galur-galur F4 hasil persilangan IR36 dan Padi Merah PWR masih mempunyai keragaman panjang malai (Tabel 3). Distribusi sebaran data 
panjang malai relatif normal seperti gambar $4 . \quad \mathrm{cm}$ dan IR $3621,5537 \mathrm{~cm}$.

Populasi F4 masih bersegregasi yang bersifat

Panjang malai merupakan salah satu transgresif pada karakter panjang malai. parameter penentu produktivitas tanaman padi. Menurut Diptaningsari (2013) Panjang malai Malai yang panjang memiliki potensi menghasiltanaman padi dapat dibedakan menjadi tiga kan gabah lebih banyak. Menurut Nur (2013) kelas antara lain kelas malai pendek $(<20 \mathrm{~cm})$, karakter panjang malai ditentukan oleh pasokan sedang $(21-30 \mathrm{~cm})$ dan panjang $(>30 \mathrm{~cm})$. asimilat yang terjadi pada fase vegetatif sebagai Tanaman terpilih memiliki panjang malai kriteria sumber untuk membentuk malai dan biji pada sedang sampai panjang yaitu antara 24 sampai fase generatif. Karekter panjang malai meng$28 \mathrm{~cm}$. Tanaman terpilih memiliki panjang malai gambarkan kemampuan tanaman dalam transdiantara tetuanya yaitu Padi Merah PWR 29,33 lokasi fotosintat ke malai.

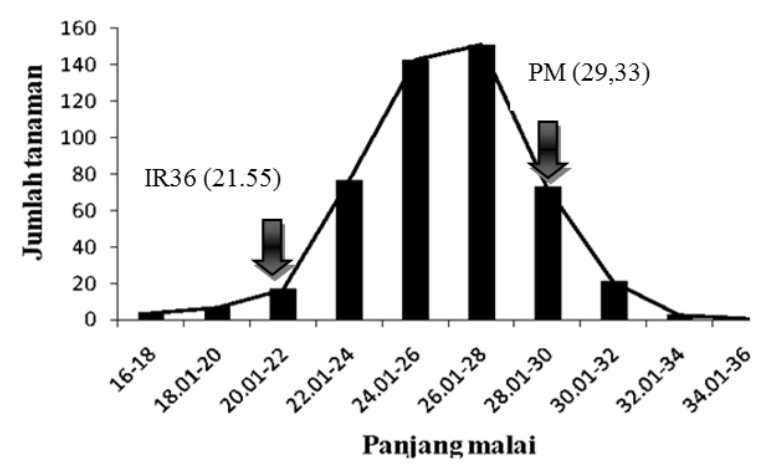

Gambar 2. Pola sebaran keragaman populasi F4 hasil persilangan

IR 36 dengan padi merah berdasarkan panjang malai

f. Jumlah gabah per malai

Karakter jumlah gabah per malai populasi

F4 hasil persilangan IR 36 dengan Padi Merah PWR masih menunjukkan keragaman (Tabel 3). Hasil analisis varian terhadap tetua IR 36 dan Padi Merah PWR pada karakter jumlah gabah per malai menunjukkan ada beda nyata (Tabel 2). Pola sebaran data panjang malai tidak terdistribusi normal (Gambar 3). Hasil rilis varietas padi sawah dari Departemen Pertanian memiliki jumlah gabah per malai minimal 100 bulir (Suprihatno et al., 2009). Seleksi galurgalur hasil persilangan padi IR 36 dengan Padi Merah PWR diperoleh 92 galur yang memiliki jumlah gabah per malai minimal 100 bulir. Galur terseleksi memiliki jumlah gabah per malai antara 71 bulir sampai 133 bulir (Tabel 4), lebih baik dari IR 36 sebanyak 65 bulir dan padi merah sebanyak 125 bulir (Tabel 2). 


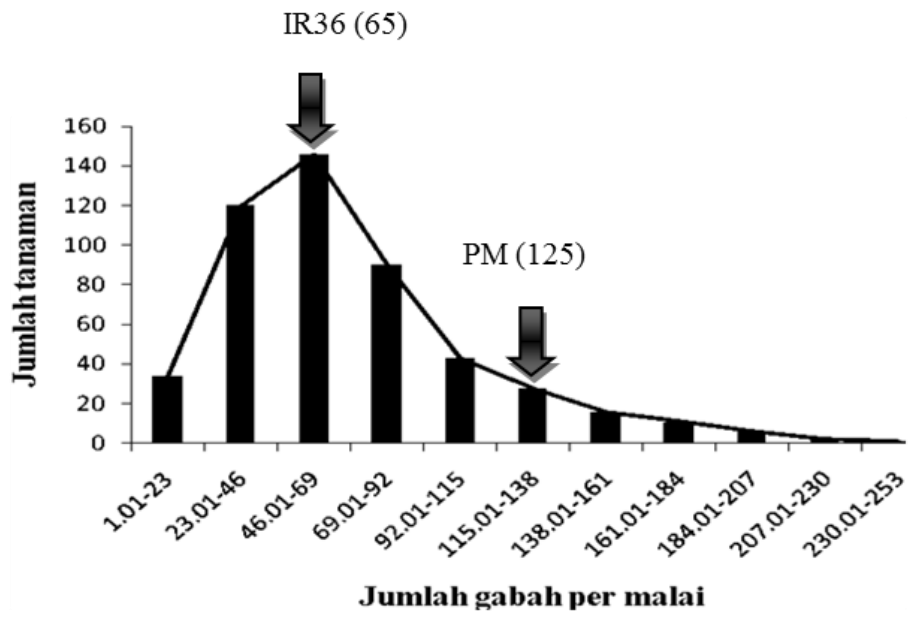

Gambar 3. Pola sebaran keragaman populasi F4 hasil persilangan

IR 36 dengan padi merah berdasarkan jumlah gabah per malai

Jumlah gabah permalai berkaitan langsung dengan panjang malai dan bobot per rumpun. Peningkatan jumlah gabah dalam malai memberikan kontribusi terhadap peningkatan hasil gabah (Sutaryo, 2015). Hasil tanaman padi ditentukan oleh bobot gabah/biji. Bobot biji per malai yang semakin berat menunjukan jumlah gabah per malai tinggi (Zecevic et al., 2010).

\section{g. Bobot 1000 biji}

Hasil analisis varian terhadap populasi F4 hasil persilangan IR 36 dengan Padi Merah PWR dan tetuanya tidak terdapat keragaman pada karakter bobot 1000 biji (Tabel 2 dan 3). Varietas padi sawah yang sudah dirilis Departemen Pertanian memiliki bobot 1000 biji minimal $21 \mathrm{~g}$ (Suprihatno et al., 2009). Seleksi tanaman terpilih memiliki bobot 1000 biji antara 22,3 g sampai 26,7 g (Tabel 4). Populasi F4 sudah menunjukkan ada perbaikan karakter bobot 1000 biji dari tetuanya, yaitu IR 36 dan Padi Merah PWR sebesar $23 \mathrm{~g}$ (Tabel 2). Besar kecilnya bobot 1000 biji dipengaruhi oleh berat per bulir, semakin berat bulir maka bobot 1000 biji semakin berat dan bobot gabah per malai semakin tinggi. Ukuran gabah yang lebih berat menyumbang hasil tinggi (Mugiono et al., 2009). h. Bobot Gabah Per Rumpun

Pada bobot gabah per rumpun terdapat keragaman antar galur hasil persilangan IR 36 dengan Padi Merah PWR (Tabel 3). Keragaman bobot gabah per rumpun tidak terdistribusi normal tersaji pada Gambar 4. Tujuan persilangan IR 36 dan Padi Merah PWR adalah mendapatkan galur harapan yang memiliki potensi hasil tinggi dan tekstur nasi yang pulen. Rata-rata hasil varietas IR $36 \quad 4,5$ ton/ha (Suprihatno et al., 2009), Padi Merah adalah varietas lokal yang produktivitasnya masih rendah (Hartina et al., 2017). Untuk mendapatkan tanaman dengan hasil lebih dari 4,5 ton/ha, tanaman dipilih yang memiliki bobot gabah per rumpun minimal $25 \mathrm{~g}$ per rumpun. Pada penelitian ini, galur-galur terpilih memiliki bobot gabah per rumpun antara $37,8 \mathrm{~g}$ sampai $53,7 \mathrm{~g}$, lebih baik dari tetuanya yaitu IR $3624,6 \mathrm{~g}$ dan Padi Merah PWR 29,8 g.

Bobot gabah per rumpun berkaitan dengan persentase antara bobot gabah hampa dan bobot gabah bernas, panjang malai, anakan total dan anakan produktif. Jumlah anakan 
produktif yang sedikit berpengaruh terhadap jumlah gabah dalam satu malaipun tinggi. penurunan bobot gabah per rumpun (Hatta, Menurut Natawijaya (2012) Jumlah gabah 2011). Panjang malai juga berpengaruh bernas yang semakin tinggi akan diikuti dengan terhadap jumlah gabah per rumpun karena peningkatan bobot gabah per rumpun. semakin panjang suatu malai kemungkinan

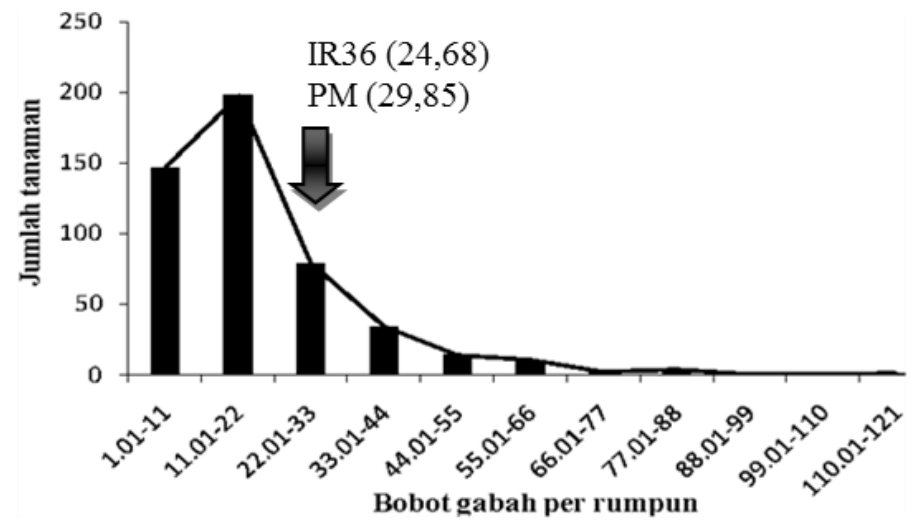

Gambar 4. Pola sebaran keragaman populasi F4 hasil persilangan IR 36 dengan padi merah berdasarkan bobot gabah per rumpun

Seleksi Galur- Galur F4 yang akan Diteruskan Menjadi Generasi F5

Galur-galur F4 yang sudah dikelompokkan berdasarkan kriteria padi ideal menurut variabel pengamatan kemudian diseleksi lebih lanjut berdasarkan variabel yang berbeda nyata. Tujuan seleksi adalah untuk mendapatkan tanaman yang diinginkan, yaitu beras merah yang berproduksi tinggi dan bertekstur nasi pulen. Kandungan amilosa pada beras adalah parameter dalam menentukan beras pulen atau pera. Menurut IRRI (2009) beras berdasar kandungan amilosanya dibagi menjadi lima golongan, yaitu: (1) beras dengan amilosa tinggi (25-33\%); (2) beras dengan amilosa sedang
(20-25\%); (3) beras dengan amilosa rendah (10$20 \%$ ); (4) beras dengan amilosa sangat rendah (2-9\%); (5) ketan (12\%).

Hasil seleksi berdasarkan karakter agronomik, diperoleh 6 individu yang mempunyai potensi hasil tinggi (Tabel 4). Analisis kandungan amilosa dilakukan pada 6 individu terpilih dan 3 individu pembanding yang dipilih secara random. Hasil analisis kandungan amilosa (Tabel 5) menunjukkan individu IRPM11219442 dan IRPM11219444 memiliki kandungan amilosa kategori tinggi, sedangkan pada individu lain masuk kategori kandungan amilosa sedang. 
Tabel 4. Data tanaman terpilih populasi F4 hasil persilanga IR 36 dengan padi merah

\begin{tabular}{lcccccccc}
\hline Varietas Cek & UB & TT & JAT & JAP & JGM & BSB & PM & BGPR \\
\hline IRPM11219442 & 49,8908 & 114,79 & 29,8025 & 24,7942 & 71,7575 & 26,7892 & 25,7234 & 38,8325 \\
IRPM11219444 & 59,8908 & 119,69 & 19,7942 & 18,8025 & 125,76 & 25,6892 & 24,8234 & 53,7825 \\
IRPM11224542 & 59,7883 & 106,48 & 56,6775 & 20,0617 & 122,42 & 25,9142 & 32,8682 & 42,7412 \\
IRPM11224543 & 54,7883 & 115,68 & 27,6775 & 16,0617 & 110,42 & 22,9042 & 28,2682 & 37,8012 \\
IRPM114218224 & 60,3208 & 119,53 & 30,52 & 15,1442 & 133,82 & 23,4167 & 24,9084 & 49,4963 \\
IRPM114218284 & 60,3208 & 113,63 & 39,52 & 25,1442 & 100,82 & 22,2967 & 28,5084 & 41,2163 \\
\hline
\end{tabular}

Keterangan: (IRPM) IR36 x Padi Merah, (UB) umur berbunga, (TT) tinggi tanaman, (JAT) jumlah anakan total, (JAP) jumlah anakan produktif, (JGM) jumlah gabah per malai, (BSB) bobot 1000 biji, (PM) panjang malai, (BGPR) bobot gabah per rumpun.

Tabel 5. Data kandungan amilosa (\%) pada tanaman terpilih dan tanaman pembanding

\begin{tabular}{llll}
\hline No. & Tanaman terpilih & Kandungan Amilosa (\%) & Kategori \\
\hline 1 & IRPM 11219442 & 26,06 & tinggi \\
2 & IRPM 11219444 & 25,63 & tinggi \\
3 & IRPM 11224542 & 22,2 & sedang \\
4 & IRPM 11224543 & 23,30 & sedang \\
5 & IRPM 114218224 & 23,81 & sedang \\
6 & IRPM 114218284 & 24,35 & sedang \\
\hline No. & Tanaman pembanding & Kandungan Amilosa (\%) & \\
\hline 1 & IRPM 114219433 & 25,28 & tinggi \\
2 & IRPM 112234745 & 24,16 & sedang \\
3 & IRPM 11219235 & 23,60 & sedang \\
\hline
\end{tabular}

Keterangan: (IRPM) IR36 $\times$ padi merah

Hasil analisis kandungan amilosa pada tanaman terpilih termasuk dalam kategori sedang sampai tinggi. Hal ini menunjukan bahwa galur F4 memiliki tingkat keragaman cukup tinggi karena dipengaruhi oleh perbedaan genetik dan lingkungan. Menurut Wang et al. (2010), beragamnya kandungan amilosa dipengaruhi oleh adanya perbedaan genetik. Beras dengan kandungan amilosa tinggi menyebabkan nasi menjadi kering, pera dan mejadi keras ketika dingin (Luna et al., 2015). Menurut Mc Clung (2000) perbedaan tekstur nasi dipengaruhi oleh lingkungan tumbuh berbeda. hal ini karena lingkungan tumbuh berpengaruh terhadap komposisi kimia yang terdapat dalam biji (Ashley, 1996). Hasil peneliti-an Anhar (2011) pada varietas varietas padi yang yang ditanam pada lingkungan yang berbeda memiliki kandungan amilosa yang tidak berbeda dikarenakan varietas memiliki genetik yang sama (stabil). Hasil penggabungan analisis karakter agronomik dan kandungan amilosa diperoleh empat individu F4 hasil persilangan IR36 dan Padi Merah PWR yang layak diteruskan menjadi generasi F5 yaitu IRPM 114218284, IRPM 114218224, IRPM 11224542, IRPM 11224543. 


\section{KESIMPULAN}

1. Pada populasi $\mathrm{F} 4$ hasil persilangan IR 36 dan Padi Merah PWR masih terdapat keragaman karakter agonomi pada variabel umur berbunga, jumlah gabah permalai, panjang malai dan bobot gabah per rumpun.

2. Berdasarkan seleksi karakter agronomi dan analisis kandungan amilosa tanaman F4 hasil persilangan IR 36 dan Padi Merah, terpilih 4 tanaman yang dapat dilanjutkan menjadi generasi F5 yaitu, IRPM 114218284, IRPM 114218224, IRPM 11224542 , IRPM 11224543.

3. Kandungan amilosa pada individu terseleksi masuk dalam kategori sedang, sehingga galur tersebut memiliki tekstur yang lebih disukai dibandingkan kedua tetuanya.

\section{UCAPAN TERIMA KASIH}

Ucapan terima kasih disampaikan kepada LPPM Universitas Jenderal Soedirman yang telah mendanai penelitian ini melalui Skema Riset Unggulan Tahun Anggaran 2016. Ucapan terima kasih disampaikan juga kepada Sdr. Sri Andi Astuti, Sdr. Mufti, Bapak Nandi dan laboran Laboratorium Pemuliaan Tanaman dan Bioteknologi Fakultas Pertanian Unsoed Purwokerto yang telah membantu selama penelitian berlangsung.

\section{DAFTAR PUSTAKA}

Ashley, JM. 1996. Kacang Tanah: Fisiologi Tanaman Budidaya Tropik (Eds. Goldswhorty and Fisher. Gajah Mada University Press. Yogyakarta.

Anhar, A. 2011. Stabilitas kandungan amilosa beras beberapa varietas padi sawah di sumatera barat. Jurnal Sainstek. 3(1):2124.

Carsono, N., 2009. Peran pemuliaan tanaman dalam meningkatkan produksi pertanian di Indonesia. [Internet].[Diunduh tanggal 2 Oktober 2016] tersedia pada https:// pustaka.unpad.ac.id/.

Departemen Pertanian, 2000. Klasifikasi umur padi [Internet] [diunduh tanggal 2 Februari 2018] tersedia pada bbpadi.litbang.pertanian.go.id/index.php/ tahukah-anda/120-kalsifikasi-umur-padi.

Diptaningsari, D. 2013. Analisis keragaman karakter agonomis dan stabilitas galur harapan padi gogo turunan padi local pulau buru hasil kultur antera. [Disertasi]. Progam Pascasarjana, Institut Pertanian Bogor. Bogor.

Fadjry D, Arifuddin K, Syafruddin K, Nicholas. 2012. Pengkajian Varietas Unggul Baru Padi yang Adaptif pada Lahan Sawah Bukaan Baru untuk menigkatkan produksi> 4 ton/ha GKP di Kabupaten Merauke Provinsi Papua. Balai Pengkajian Teknologi Pertanian Sulawesi Selatan dan Balai Pengkajian Teknologi Pertanian Papua; Sulawesi Selatan.

Federer WT. 1961. Augmented design with one-way elimination of heterogeneity. Biometrics. 17:447-473.

Guimarães, E. P. 2009. Rice Breeding. In cereals, the banks and the italian 
economy. M.J. Carena (ed.), O Springer

Science + Business Media, LLC. 99-126.

Hartina B.S, A.A.A.K Sudharmawan, Muhammad Dahla. 2017. Uji sifat kuantitatif dan hubungannya dengan hasil galur harapan padi beras merah (Oryza sativa L.) di dataran tinggi. Crop Ago. 10(1).

Hatta Muhammad. 2011. Pengaruh tipe jarak tanam terhadap anakan, komponen hasil, dan hasil dua varietas padi pada metode SRI. J. Floratek. 6:104-113.

IRRI. 2009. Reference Guide Standard Evaluation System for Rice. [Internet] [diunduh tanggal 16 Oktober 2018] tersedia pada http://www.knowledge bank.irri.org/.

Jambormias, E. And J. Riry. 2009. Data adjusment and use of information from relatives to detect the transgesive segegant of quantitatif traits in self pollinated crops (an aproach in selec tion). Jurnal Budidaya Pertanian 5:11-18.

Luna, Prima, Heti Herawati., Sri Widowati, dan Aditya B, Prianto. (2015). Pengaruh kandungan amilosa terhadap karakte ristik fisik dan organoleptik nasi instan. Jurnal Penelitian Pascapanen Pertanian. 12(1):1-10

Mc Clung, AM. 2000. Rice Breeding Gets Marker Assists. Agricultural Research Magazine. Dalam http://www.ars.usda.
gov/is/AR/archive/dec00/rice $1200 \mathrm{html}$. 23 Juli 2006.

Mugiono, L. Harsanti, A.K. Dewi. 2009. Perbaikan padi varietas cisantana dengan mutasi induksi. Jurnal Ilmiah Aplikasi Isotop dan Radiasi.5(2):194-210

Mulyaningsih, Enung Sri., Ambar Yusni Perdani., Sri Indrayani., Suwarno, (2016). Seleksi fenotip populasi padi gogo untuk hasil tinggi, toleran alumunium dan tahan blas pada tanah masam. Jurnal Penelitian Tanaman Pangan. 31(3).

Natawijaya, A. 2012. Analisis genetik dan seleksi generasi awal segregan gandum (Triticum Aestivum L.) Berdaya hasil tinggi. [Tesis]. Sekolah Pascasarjana. Institut Pertanian Bogor. Bogor.

Nur, A. 2013. Adaptasi tanaman gandum (Triticum Aestivum L.) Toleran suhu tinggi dan peningkatan keragaman genetik melalui induksi mutasi dengan menggunakan iradiasi sinar gamma. [Disertasi]. Sekolah Pascasarjana. Institut Pertanian Bogor. Bogor.

Perwira, Adhy Dharma. 2004. Keragaan karakter agonomi generasi f3 persilangan enam varietas padi gogo. [Skripsi]. Fakultas Pertanian IPB, Bogor.

Romadhoni, A., Elza Z, dan Deviona. 2012. Genetic variability and heritability 20 genotipe of high yield chili (Capsicum 
annum L.) IPB collection. Universitas Riau. Riau.

Sikuku PA, Kimani JM, Kamau JW, Njinju S. 2015. Evaluation of different improved upland rice varieties for low soil nitrogen adaptability. Inter J. Plant and Soil Sci. 5(1):40-49.

Suardi D K, 2005. Potensi beras merah untuk peningkatan mutu pangan. Jurnal Litbang Pertanian. 24(3):2.

Sutaryo, Bambang. 2015. Ekspresi hasil gabah dan analisis lintas beberapa varietas unggul baru padi. Balai pengkajian teknologi pertanian. Agros 17:55-63.

Suprihatno B, Aan A D, Satoto, Baehaki S.E. I N, Widiarta, Agus Setyono S, Dewi Indrasari, Ooy S L, Hasil S. 2009. Deskripsi Varietas Padi. Balai Besar Penelitian Tanaman Padi. Subang.

Tasliah, J. Prasetiyono, A. Dadang, M. Bustamam, dan S. Moeljopawiro. 2011. Studi agronomis dan molekuler padi umur genjah dan sedang. Berita Biologi 10(5):663-673.

Wang, D., Feng, Y., Liu, J., Yan, J., Wang, M., Saki, J. 2010. Black garlic (Allium sativum L.) extracts enhance the immune system. Medicinal and Aromatic Plant Science and Biotechnology. 4:37-40.

Widyayanti, S., Panjisakti, B., Suyadi, M., Kristamtini. 2017. Keragaman genetik dan heritabilitas karakter agronomi galur
F4 padi beras hitam. Penelitian Pertanian Tanaman Pangan 1(3).

Yang, W.H., S.B. Peng, M.L. Dionisio-Sese, R.C. Laza, and R.M. Visperas. 2008. Grain filling duration, a crucial determinant of genotypic variation of gain yield in field-grown tropical irrigated rice. Field Crops Res. 105:221-227.

Zecevis, V., J. Boskovic, M. Dimitrijevic, S. Petrovic. 2010. Genetic and phenotypic variability of yield components in wheat (Triticum aestivum L.). Bulg. J. Agic. Sci. $16: 422-428$ 